\title{
Turning Iraq into a country of energy exporter through the exploitation of solar energy and vast desert land
}

\author{
Abass Ahmed. Z. ${ }^{1}$, Pavlyuchenko.D.A ${ }^{2}$ \\ ${ }^{1}$ Novosibirsk State Technical University, Industrial Power Supply Systems Novosibirsk, 630073, Russia, Ph.D. student. \\ ${ }^{2}$ Novosibirsk State Technical University, Industrial Power Supply Systems, Ph.D., Associate Professor, Head of Department, \\ Novosibirsk, 630073, Russia
}

\begin{abstract}
The Iraqi government and people are not fully aware of the importance of renewable energy, so developing renewable energy technology in the region is primarily and a result of individual's initiatives and non-governmental organizations instead of official policy. The fossil fuel is not limitless though in the next hundred years will be vanished, the only continuous resource is the solar energy as a solution to hinder the $\mathrm{CO}_{2}$ emission from various sources of fossil and biofuel. The solar energy requires an immediate attention due to the climatic change that affects the global warming. Iraq is a region rich in solar energy, where the sun's brightness increases more than 3300 hours a year. The solar radiation falling in the desert areas of Iraq, which now accounts for more than $60 \%$ of the country's area. $437072 \mathrm{~km}^{2}$ is equal to hundreds of thousands of times the total energy generated in this country. This is given Iraq a hand to stay as an energy supplier in the future as well as the present supplier of energy in the form of fossil fuel. Iraq consists of 18 provinces, three of which are in the northern province of the Kurdistan region and each province has the powers of semi-independent and special budget allocated by the central government where the provincial councils can invest part of this budget in the establishment of solar power stations, especially the provinces that suffer from lack of energy through the exploitation of other areas (deserts) to create such stations. the middle and south of Iraq have an averaged from 16 to $10 \mathrm{MJ} / \mathrm{m}^{2} /$ day for 5 months in the north, 6 months in the middle and southern region, respectively. But in western desert of Al-Anbar district almost have 8 month of sun shine duration while the lowest is over $4 \mathrm{MJ} / \mathrm{m}^{2} /$ day. This energy is quite sufficient to drive all thermal photovoltaics (PV), Integrated Solar Combined Cycle (ISCC) plant and all houses hold facilities of heating, cooling and water distillation along the year.
\end{abstract}

\section{Introduction}

Since 1980 until today, Iraq has been in a continuous war and has destroyed all the infrastructure. In 1980, the Iran-Iraq war started, which continued for eight years. This war caused an increase in government spending on war and reduced spending on infrastructure, especially electricity. In 1991, the first Gulf War sparked when the US-British-French coalition launched the worst campaign in human history to destroy all infrastructures. This brutal aggression targeted all the country's power plants indiscriminately and caused over $95 \%$ destruction at all stations. After this war and the destruction of this country, the United States and its allies from the coalition countries imposed resolutions through the United Nations the blockade of Iraq and expose its citizens of starvation and causing severe shortages of food and medicine and continued this siege until the invasion of Iraq in 2003 and occupation by the aggressor countries headed by United State.

All these unjust acts of aggression have destroyed the infrastructure of Iraq's power plants. Today, in 2018,
Iraq still suffers from a severe shortage in the processing of electricity to citizens, noting that $90 \%$ of the factories and government buildings are still out of work. The demand for electricity in Iraq increased from $11000 \mathrm{MW}$ in 2007 to $16000 \mathrm{MW}$ in 2013, to $245000 \mathrm{MW}$ in summer 2018, and is expected that this demand will be increased to more than $30000 \mathrm{MW}$ in 2020 [1].

The Iraqi Ministry of Electricity has identified the shortage in the production of electricity up to $6000 \mathrm{MW}$ increasing during the summer because of the need to use air conditioners in this hot season of the year, which runs from May until the end of September [2,3]. The bulk of the country's citizens rely on small or medium-sized generators (not more than one megawatts) to compensate for the lack of government processing. These generators work with Iraqi gasoline and diesel, which both represent the worst fuels in the world because they contain large amounts of sulfur that meaning more and more pollution. The operation of these generators causes high noise as well as the emission of millions of tons of air pollutants and greenhouse gases. It is believed that the several generators operating in Iraq exceeded two

theking.amir@mail.ru 
million generators of all sizes. The use of renewable energies in Iraq is still very late and does not exceed some of the dams that produce hydroelectric power and some shy projects to use photovoltaic (PV) systems whose capacity does not exceed $10 \mathrm{~kW}$.

The Iraqi government should use solar energy to produce electricity as one of its future goals as part of its focus on reducing environmental damage and pollution of the country's atmosphere, soil, and water as well as working to find the best ways to use renewable energy in the country. The availability of renewable energy sources locally and renewable, in addition to being environmentally friendly, is one of the most important factors determining the choice of new sources of energy. It can be said that solar energy in Iraq meets all these requirements. The level of solar energy density in this country is very high and among the desirable rates globally where it exceeds in some areas 2200 $\mathrm{kWh} / \mathrm{m} 2 /$ year. As it is free energy for all, renewable for a long time, and does not harm the environment. The Iraqi government should invest in renewable energies by means of the large revenues from oil sales and the exploitation of the great desert lands, which is considered one of the best places in the world in terms of the number of hours of sunrise and estimated about 3300 hours during the year as well as the amount of radiation on it.

\section{Solar energy perspectives in Iraq}

Countries in the Arabian Peninsula have not adopted solar energy because of the cheap and plentiful supply of oil. At present, governments and the public have no incentive to consider alternative forms of energy, and protecting the environment is not a high priority in the region. The government and people of Iraq are not fully aware of the importance of renewable energy, and therefore, the development of related technology within the region is primarily the result of each initiative and non-governmental organizations.

Although there is an abundance of fossil fuels in Iraq, energy shortages began in 1991 because of the disruption caused by the full-scale destruction of the country. The obvious renewable energy resource available in Iraq is the solar energy, and its exploitation would give a means to reduce $\mathrm{CO}_{2}$ emissions from the burning of fossil fuels. Solar energy is becoming increasingly important because of the climatic change in the form of global warming. The $233 \mathrm{PW}$ of solar energy that reaches the surface of the earth annually is plentiful compared with the $24 \mathrm{TW}$ of the average annual power consumption by human activities. Global deserts receive more energy from the sun than is consumed annually by the world's population. The desert in Western Iraq has the greatest solar electricity generation capacity 1776 $\mathrm{MJ} / \mathrm{m}^{2}(492333 \mathrm{kWh})$ of all the regional deserts. Iraqi deserts alone generate a mean power density of 3140$3373 \mathrm{MJ} / \mathrm{m}^{2}$, (872222-937000 $\left.\mathrm{kWh}\right)$ reaching a peak power density of $26860 \mathrm{MJ} / \mathrm{m}^{2} /$ year according to the German Aerospace Center [4,5].
This gives Iraq the potential to stay a world energy supplier in the future but reliant on solar power not on fossil fuels. The continued progress and development of societies and the need to give conditions of comfort, both in housing and transport, have greatly increased global energy demand. Rising demand for energy caused an increase in fossil fuel consumption, which is expected to be depleted soon (Figure 1,2 ).

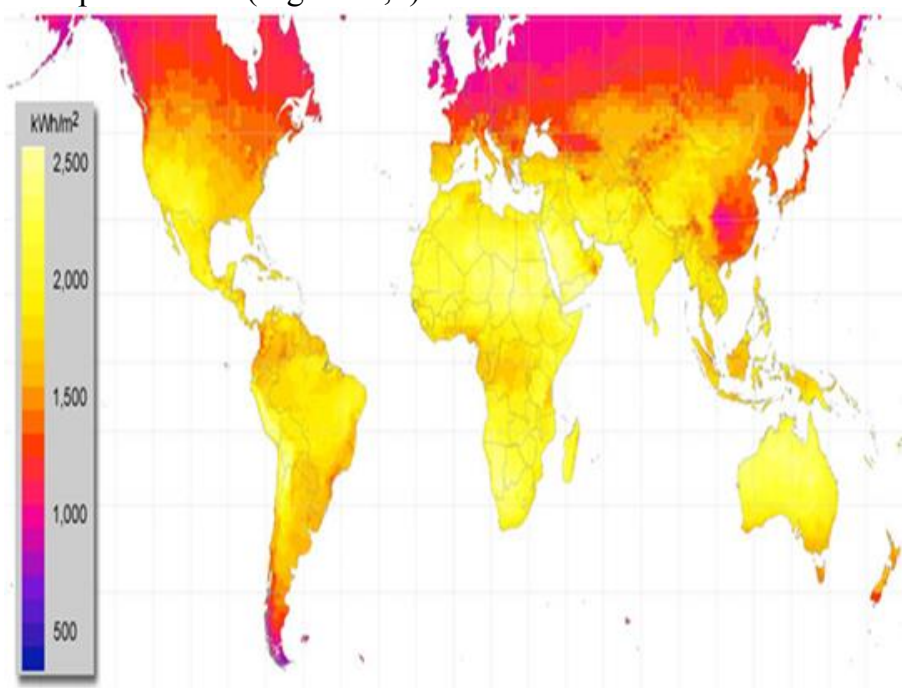

Fig.1. Iraq location at global irradiance (1850-2400 $\mathrm{kwh} / \mathrm{m}^{2}$ )

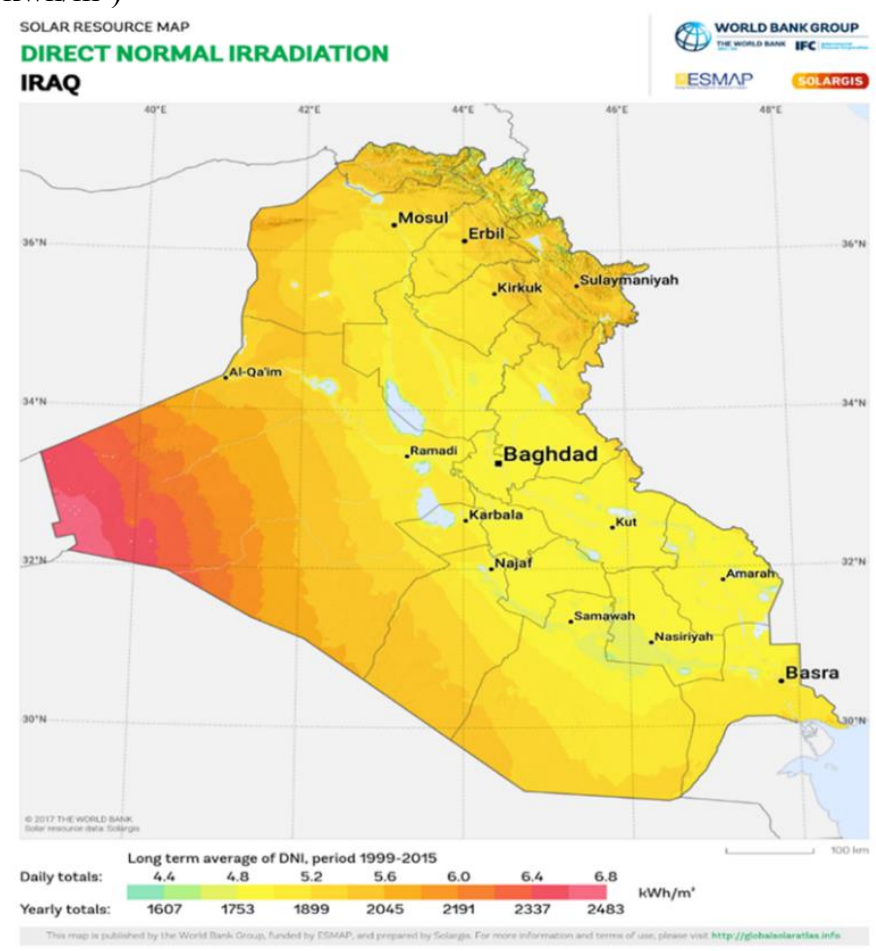

Fig.2. Iraq solar density

The trend towards renewable energies are growing around the world in an impressive way. The production of electricity using solar energy has become available and an acceptable option around the world [6]. In Iraq solar energy can be considered the best and most logical alternative to burning fossil fuels. The solar energy falling to the ground in one hour is enough for a full year of electricity to all the earth if used properly. There is no denying that energy availability is important in the 
progress and development of societies. It also provides solutions to other dilemmas such as water, food, environment, health, education, climate protection, information, communication and mobility. An enough amount of environmentally friendly energy that reduces high air pollution and reduces greenhouse gases is one of the biggest challenges facing the planet today. Solar energy can be used in many applications and not fossil fuels. It can be used to heat the water in the residential buildings and factories. This energy can also be used to heat the air for home and laboratory heating purposes. It is also now used to heat the Trombe walls to store heat for ventilation and heating for the comfort purposed in houses and buildings. One of the most promising applications for the use of solar energy is water distillation.

Water is the lifeblood and the provision of adequate drinking water to revive residential communities away from urbanization. The most important applications of solar energy today are in the production of electricity and either by concentrated heating or using photovoltaic cells. Solar heat is used to heat the air that rotates wind turbines in solar chimney systems, as it is used in concentrated power plants to generate electricity. As for the solar cells, part of this fallen radiation is used in the production of electricity, while the largest part goes to heat the cell. Today, the use of photovoltaic thermal $(\mathrm{PV} / \mathrm{T})$ systems is an excellent, realistic, and promising alternative. In these systems, the photovoltaic cell is cooled using a cooling fluid, whether air, water or kinds of nanofluids, to increase its electrical output and to use the heat absorbed in other applications [6].

The crystalline solar cells have many advantages. They are efficient, reliable with long lifetime and have a long record of proven durability. Therefore, they are often the preferred solution for solar-based electricity production on buildings. On the other hand, thin-film solar panels are less efficient and have a shorter lifetime. However, thin-film technology is increasingly used in small applications. It is generally expected that in the long term, thin-film technology with multi-layer cells will be widely used and attain efficiencies beyond $25 \%$. The major advantage of thin-film is that they use less material and are therefore potentially less expensive than conventional PV technology. The use of PV technology to produce electricity has become known and popularly accepted these days. Photovoltaic systems are used outside or connected to the electrical grid (producing electricity directly to the network system). Photovoltaic cells outside the grid are used in small power systems linked to diesel power generators as an alternative to dust storms or clouds. Both these types of PV systems can be used in Iraq. Solar photovoltaic technology is suitable for generating electricity in rural desert areas away from the grid in particular. Iraq is rich in solar resources and when using hybrid solar power plants and diesel generators in remote logic, it can reduce fossil fuel discharges to a large extent.

\section{Solar density in Iraqi desert}

PV electricity can be considered as the main alternative and the most possible application of solar energy. That solar energy is energy available everywhere and free of pollutants and a true friend of the environment, as the end is not subject to geographical or political restrictions and does not cause consumption of any fuel. At the same time, building the photovoltaic system requires short construction periods, small or medium size design systems can also be provided, so the design size of the PV plant is flexible and can be used directly and can be easily stored or redeployed in other areas. Photovoltaic systems can be joined with buildings. The study of the feasibility of solar energy in Iraq (current and future situation) requires us to discuss the following points: the status of energy in Iraq, the solar density in Iraqi desert; the benefits of using solar energy in Iraq. Iraq is a region rich in solar energy, where the sun's brightness increases more than 3300 hours a year (Figure 2). The solar radiation falling in the desert areas of Iraq, which now accounts for more than $60 \%$ of the country's area. $437072 \mathrm{~km}^{2}$ is equal to hundreds of thousands of times the total energy generated in this country.

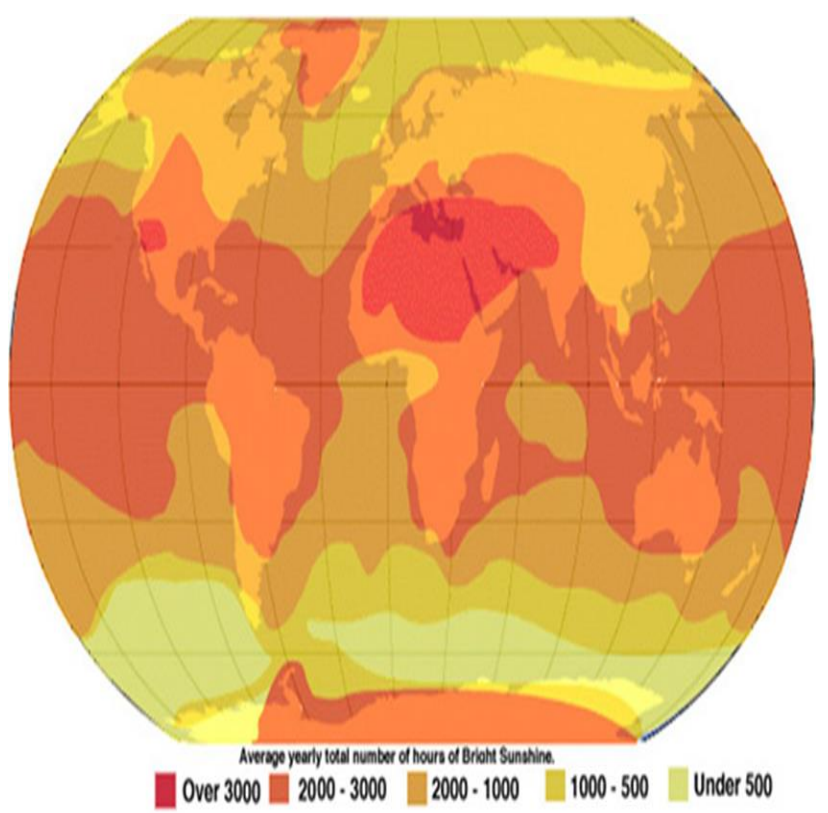

Fig. 3. Average yearly total numbers of hours of bright sunshine

Iraq has a high-density solar card available across the country from north to south. The occurrence of this country in the Middle East, on the north-eastern edge of the Arabian Peninsula, is adjoining the region of the solar system.

The climate in this country is very hot, with temperatures reaching 52 degrees Celsius during the hot summer from the beginning of May to the end of September. The climate in Iraq is generally dry (the rainfall is very small and in small amounts) and the atmosphere is very high. But the weather is humid in the southern coastal area of Basra province, the most popular days of the year. Air conditions such as the heat of the atmosphere associated with high solar radiation, humidity and dust, as well as lack of rain, can be 
considered as barriers to reducing the use of photovoltaic systems.

Desert areas in Iraq, it's about to $220000 \mathrm{~km}^{2}$ and especially near the Saudi Arabian Empty Quarter, areas of high solar density. The entire area of Iraq can be considered to have a suitable solar intensity for the operation of photovoltaic stations. The solar density of Iraq is approaching the density of the solar belt states, which are considered one of the highest solar densities in the world. According to the Iraqi studies [7], solar energy in Iraq has the ability to provide enough electricity to meet all the needs of local electricity in addition to the provision of significant quantities of electricity for export.

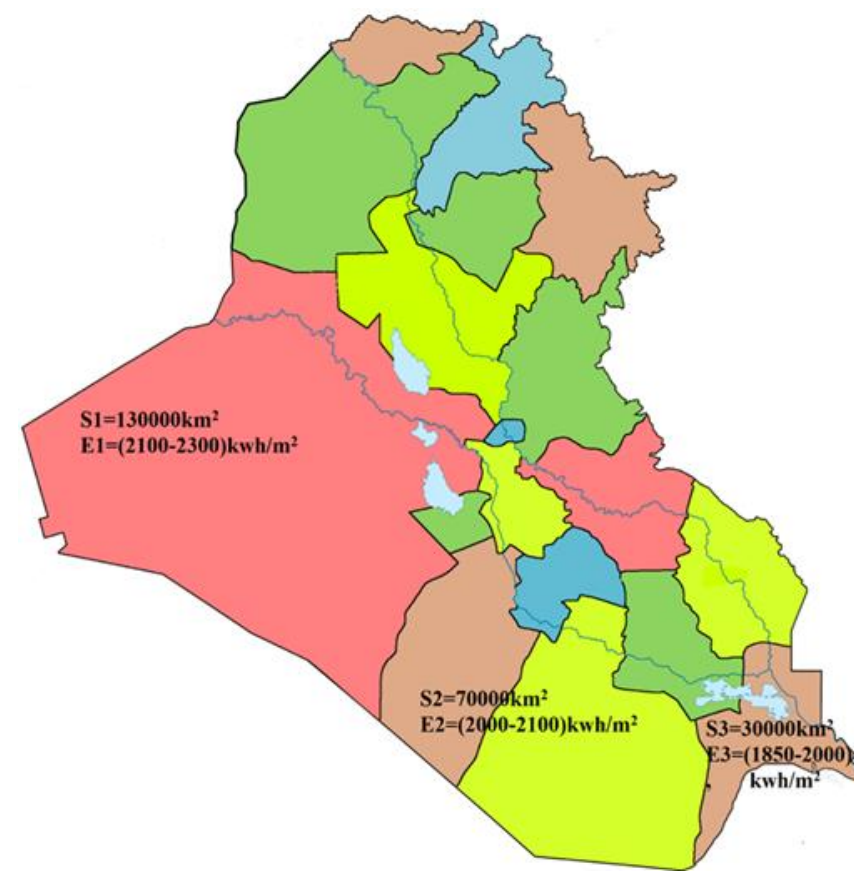

Fig. 4. Considered Iraqi desert areas

We calculate the energy that can be produced for each region according to the following equation $[5,8,9]$ :

$$
\mathrm{E}=\mathrm{A} \cdot \mathrm{r} \cdot \mathrm{H} \cdot \mathrm{PR},
$$

where E - energy, kWh; A - total solar panel area, $\mathrm{m}^{2} ; \mathrm{r}$ - solar panel yield (\%) $\eta(15 \%$ to $24 \%) ; \mathrm{H}$ - annual average irradiation on tilted panels (shadings not included), $\mathrm{kWh} / \mathrm{m}^{2}$.an; $\mathrm{PR}$ - performance ratio, coefficient for losses (range between 0.9 and 0.5 , default value $=0.75$ ).

Losses details (depend of site, technology, and sizing of the system):

- Inverter losses (6-15\%)

- Température losses (5-15\%)

$8 \%$

- $\quad$ DC cables losses (1-3\%)

- $\quad$ AC cables losses (1-3\%)

$2 \%$

$2 \%$

$3 \%$

$\begin{array}{lll}\text { - } & \text { Losses weak irradiation (3-7\%) } & 3 \% \\ \text { - } & \text { Losses due to dust, snow (2\%) } & 2 \%\end{array}$

$\begin{array}{lll}\text { - } & \text { Losses weak irradiation (3-7\%) } & 3 \% \\ \text { - } & \text { Losses due to dust, snow (2\%) } & 2 \%\end{array}$

$0 \%$

- $\quad$ Other losses

1- The first region is located between the provinces of Anbar and Karbala estimated at about $130000 \mathrm{~km} 2$ (Bottom-left: Latitude 31.9831, Longitude 39.1303, Upper-right: Latitude 33.5168, Longitude 42.9096).
Table 1. Solar radiation falling at first region at 2017, $\mathrm{kWh} / \mathrm{m}^{2}[5,10]$

\begin{tabular}{|c|c|c|c|c|c|c|c|c|}
\hline Lat & Lon & Jan & Feb & Jun & Jul & Aug & Dec & Ann \\
\hline 31.75 & 39.25 & 3.52 & 4.86 & 8.52 & 7.91 & 7.56 & 3.22 & 5.96 \\
\hline 31.75 & 41.75 & 3.5 & 4.81 & 8.43 & 8 & 7.43 & 3.2 & 5.86 \\
\hline 31.75 & 42.25 & 3.51 & 4.69 & 8.34 & 7.88 & 7.33 & 3.22 & 5.76 \\
\hline 32.25 & 39.75 & 3.46 & 4.52 & 8.52 & 8.06 & 7.56 & 2.94 & 5.85 \\
\hline
\end{tabular}

Using previous equation (1) and all the required data, we can say that the value of energy available during one year is: $31424 \mathrm{PWh} /$ year.

2-The second region is located between the provinces of the Najaf, Diwaniyah and Samawa estimated at about $70000 \mathrm{~km}^{2}$ (Bottom-left: Latitude 29.1481, Longitude 43.7570, Upper-right: Latitude 31.7429, Longitude 45.9542).

Table 2. Solar radiation falling at second region at 2017, $\mathrm{kwh} / \mathrm{m}^{2}[5,10]$

\begin{tabular}{|c|c|c|c|c|c|c|c|c|}
\hline Lat & Lon & Jan & Feb & Jun & Jul & Aug & Dec & Ann \\
\hline 29.25 & 43.75 & 3.79 & 5 & 8.31 & 7.84 & 7.3 & 3.65 & 5.92 \\
\hline 29.75 & 45.75 & 3.73 & 4.65 & 8.17 & 7.77 & 7.2 & 3.52 & 5.77 \\
\hline 30.25 & 43.75 & 3.63 & 4.88 & 8.3 & 7.77 & 7.31 & 3.46 & 5.82 \\
\hline 30.75 & 45.75 & 3.46 & 4.56 & 8.13 & 7.66 & 7.14 & 3.33 & 5.62 \\
\hline 31.25 & 43.75 & 3.44 & 4.6 & 8.27 & 7.75 & 7.29 & 3.19 & 5.66 \\
\hline 31.75 & 45.75 & 3.2 & 4.34 & 7.93 & 7.37 & 7.02 & 3.04 & 5.38 \\
\hline
\end{tabular}

3-The third region is located between the provinces of Nasiriyah and Basra, estimated about $30000 \mathrm{~km} 2$ (Bottom-left: Latitude 30.0621, Longitude 46.1469, Upper-right: Latitude 31.1965, Longitude 48.1025).

Table 3. Solar radiation falling at third region at 2017, $\mathrm{kwh} / \mathrm{m}^{2}[5,10]$

\begin{tabular}{|l|l|l|l|l|l|l|l|l|}
\hline Lat & Lon & Jan & Feb & Jun & Jul & Aug & Dec & Ann \\
\hline 30.25 & 46.25 & 3.54 & 4.42 & 7.97 & 7.53 & 7.07 & 3.29 & 5.57 \\
\hline 30.25 & 47.25 & 3.44 & 4.12 & 7.91 & 7.37 & 7 & 3.21 & 5.47 \\
\hline 30.25 & 48.25 & 3.27 & 4.16 & 7.87 & 7.28 & 6.9 & 3.14 & 5.41 \\
\hline 31.25 & 46.75 & 3.18 & 4.24 & 7.87 & 7.31 & 6.94 & 3.03 & 5.35 \\
\hline 31.25 & 47.25 & 3.13 & 4.13 & 7.82 & 7.2 & 6.87 & 3.01 & 5.33 \\
\hline 31.25 & 48.25 & 3.14 & 4.14 & 7.94 & 7.27 & 6.63 & 3.09 & 5.37 \\
\hline
\end{tabular}

By using the equation (1) and all the required data, we can say that the value of energy available during the year is: $6240 \mathrm{PWh} /$ year.

When the output of the three regions is collected, the output is as follows:

$$
\begin{gathered}
\mathrm{E}_{\mathrm{T}}=\mathrm{E}_{1}+\mathrm{E}_{2}+\mathrm{E}_{3} \\
\mathrm{E}_{\mathrm{T}}=31424+15741+6240=53405 \mathrm{PWh} / \text { year. }
\end{gathered}
$$

It is clear from the above equation that it is possible to produce a very large quantity of electricity enough to cover not only Iraq's electricity needs (215 PWh/year), but also to cover the need of some neighboring countries by exporting electricity. Where the need for Iraq represents the percentage of electricity during one year compared with the quantity produced from the exploitation of the desert is about $(0.4 \%)$ from the total production $53405 \mathrm{PWh} /$ year.

$$
\frac{215 \mathrm{PWh} / \text { year }}{53405 \mathrm{PWh} / \text { year }} * 100 \%=0.4 \%
$$




\section{Conclusions}

The using of solar energy in Iraq to generate electricity offers many benefits. Solar energy is an environmentally friendly energy: it is clean and sustainable and helps to protect its environment and reduce the damage caused by the production of electricity from fossil fuels. The use of solar energy will certainly reduce air pollution, as it will reduce the emissions of sulfur oxides, nitrogen oxides, carbon monoxide and partially burned hydrocarbons and reduce the emission of the first greenhouse gas (carbon dioxide) in the atmosphere. Solar energy is free energy, which gives it economic advantages; there is no need to spend money to buy fuel or to reduce the damage produced from using it.

The reliance on solar energy to produce electricity will reduce the dependence of the Iraqi state on nonrenewable sources. Solar systems do not require much maintenance and the highest costs are spent on the installation costs, so there are no recurring costs at all. We have some successful projects in the provinces of Najaf and Karbala, where solar power plants that do not exceed $400 \mathrm{~kW}$ have been constructed and are used to secure the electricity needed to draw water from the artesian wells and pump them back to the nearby palm groves located in the Najaf desert district. Through these projects, desert lands were reclaimed to farms and pastures that can be used for agricultural products, animal husbandry and preservation of the environment and soil.

\section{References}

1. Al-Waeli Ali A. K., Al-Asadi Kadhem A. N., "Analysis of Stand-Alone Solar Photovoltaic for Desert in Iraq", International Research Journal of Advanced Engineering and Science, Volume 3 Issue2,pp. 204209,(2018).

2. The Iraqi Ministry of Electricity URL: https://moelc.gov.iq/.

3. Abass Ahmed. Z., Pavlyuchenko.D.A, Eliminate the electricity shortage in Iraq by using PV/T panels and hybrid solar stations. IX All-Russian Scientific and Practical Conference "Scientific Initiative of foreign students and graduate students of Russian universities" (April 24 - 26, 2019, Tomsk).

4. Al-Douri Y., Abed Fayadh M., Solar Energy Status in Iraq, Journal of Renewable and Sustainable Energy, 8, 025905 (2016).

5. Abass Ahmed. Z. Pavlyuchenko.D.A, the exploitation of western and southern deserts in Iraq for the production of solar energy, International Journal of Electrical and Computer Engineering (IJECE), Vol 9, No 6.(2019).

6. Chaichan M. T., Kazem H. A., Mahdy A. M. J., AlWaeely A. A., Optimal Sizing of a Hybrid System of Renewable Energy for Lighting Street in Salalah-Oman using Homer Software, International Journal of Scientific Engineering and Applied Science (IJSEAS), vol. 2, no. 5, pp. 157-164,( 2016).
7. Ministry of Higher Education and Scientific Research URL:

http://mohesr.gov.iq/ar/ .

8. Professional site of solar PV energy and Photovoltaic software URL:

https://photovoltaic-software.com/ .

9. PV watts calculator URL:

https://pvwatts.nrel.gov .

10. Solar and meteorological data sets from NASA research for support of renewable energy, building energy efficiency and agricultural needs. URL: https://power.larc.nasa.gov/data-access-viewer . 